Edu Consilium: Jurnal BK Pendidikan Islam Vol 2, No. 1, Februari 2021, hlm. 48 - 61

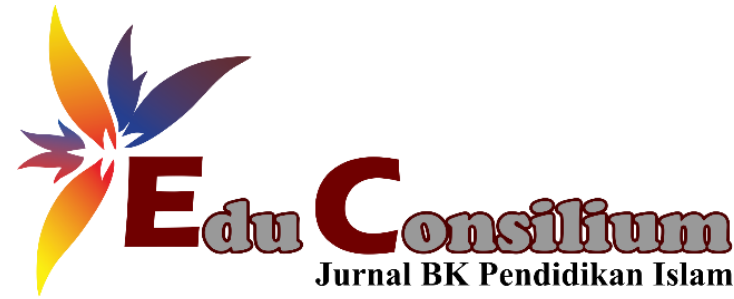

\title{
PENGARUH KINERJA GURU BIMBINGAN DAN KONSELING TERHADAP KEDISIPLINAN SISWA SMK AL-HUDA SUMBERNANGKA LARANGAN PAMEKASAN
}

\author{
Anisah Fitriana \\ Program Studi Bimbingan dan Konseling Pendidikan Islam, Fakultas Tarbiyah, IAIN Madura \\ e-mail: anisfitriana054@gmail.com
}

\begin{tabular}{|c|c|}
\hline & Abstract \\
\hline \multirow[t]{2}{*}{$\begin{array}{l}\text { Keywords: } \\
\text { Performance } \\
\text { of Guidance } \\
\text { and } \\
\text { Counseling } \\
\text { Teachers; } \\
\text { Student } \\
\text { Discipline. }\end{array}$} & $\begin{array}{l}\text { The performance of guidance and counseling teachers is a behavior that has an impact on } \\
\text { guidance and counseling services, namely in providing guidance and services, helping all } \\
\text { problems and student development in the personal-social, learning and career fields, } \\
\text { according to student needs. The purpose of this study was to determine the effect of } \\
\text { guidance and counseling teacher performance on student discipline at SMK Al-Huda } \\
\text { Sumbernangka Larangan Pamekasan. The research subjects were } 64 \text { students. Data } \\
\text { collection techniques consisted of questionnaires, observations, and documentation. The } \\
\text { data analysis technique used Product Moment correlation analysis and then simple linear } \\
\text { regression analysis was used. The results showed: } 1) \text { There was a positive and significant } \\
\text { relationship between the performance of guidance and counseling teachers and student } \\
\left.\left.\text { discipline, with a correlation coefficient of } 0.556 \text { ( } \mathrm{r}_{\text {hit }}>\mathrm{r}_{\text {tabel }} \text {, } 0.556>0.2461\right) ; 2\right) \text { The } \\
\text { higher the performance of the guidance and counseling teacher, the higher the level of } \\
\text { student discipline. The lower the performance of the guidance and counseling teacher, the } \\
\text { lower the level of student discipline; } 3) \text { There is a significant influence on the } \\
\text { performance of guidance and counseling teachers on student discipline. The performance } \\
\text { of guidance and counseling teachers has an effect on student discipline with a } \\
\text { contribution of } 31 \% \text {, while the remaining } 69 \% \text { is influenced by other factors not involved } \\
\text { in the study. }\end{array}$ \\
\hline & Abstrak \\
\hline $\begin{array}{l}\text { Kata Kunci: } \\
\text { Kinerja Guru } \\
\text { Bimbinan dan } \\
\text { Konseling; } \\
\text { Kedisiplinan Siswa. }\end{array}$ & $\begin{array}{l}\text { Kinerja guru BK merupakan perilaku yang berdampak pada layanan bimbingan dan } \\
\text { konseling, yaitu dalam memberikan bimbingan dan pelayanan, membantu semua } \\
\text { permasalahan dan perkembangan siswa dalam bidang pribadi-sosial, belajar dan karier, } \\
\text { sesuai dengan kebutuhan siswa. Tujuan dari penelitian ini adalah untuk mengetahui } \\
\text { pengaruh kinerja guru BK terhadap kedisiplinan siswa di SMK Al-Huda Sumbernangka } \\
\text { Larangan Pamekasan. Subyek penelitian sebanyak } 64 \text { siswa. Tehnik pengumpulan data } \\
\text { terdiri dari kuesioner, pengamatan, dan dokumentasi. Teknik analisis data menggunakan } \\
\text { analisis korelasi Product Moment dan selanjutnya digunakan analisis regresi linier } \\
\text { sederhana. Hasil penelitian menunjukkan: 1) Terdapat hubungan positif dan signifikan } \\
\text { antara kinerja guru BK dengan kedisiplinan siswa, dengan nilai koefisien korelasi sebesar } \\
0,556 \text { ( } \mathrm{r}_{\text {hit }}>\mathrm{r}_{\text {tabel }} \text {, 0,556 }>\text { 0,2461); } 2 \text { ) Semakin tinggi kinerja guru BK, maka akan } \\
\text { semakin tinggi juga tingkat kedisiplinan siswa. Semakin rendah kinerja guru BK, maka } \\
\text { akan semakin rendah juga tingkat kedisiplinan siswa; 3) Terdapat pengaruh yang } \\
\text { signifikan kinerja guru BK terhadap kedisiplinan siswa. Kinerja guru bimbingan dan } \\
\text { konseling berpengaruh terhadap kedisiplinan siswa dengan kontribusi sebesar } 31 \% \text {, } \\
\text { sedangkan } 69 \% \text { sisanya dipengaruhi oleh faktor lain yang tidak dilibatkan dalam } \\
\text { penelitian. }\end{array}$ \\
\hline
\end{tabular}


OEdu Consilium: Jurnal BK Pendidikan Islam

Bimbingan dan Konseling Pendidikan Islam

Institut Agama Islam Negeri Madura, Indonesia

\section{PENDAHULUAN}

Pendidikan merupakan proses pembelajaran yang dilakukan oleh pendidik sebagai upaya mencerdaskan dan mendewasakan peserta didik (Susanto 2010). Pendidikan merupakan sebuah usaha secara sadar, terencana, dan terstruktur yang dilaksanakan dalam rangka menciptakan kondusivitas pembelajaran serta proses pembelajaran itu sendiri agar siswa sebagai peserta didik mampu mengeksplor potensi dirinya secara aktif, sehingga mempunyai akhlak mulia yang ditunjukkan melalui kepribadian dan pengendalian diri yang baik, spiritual keagamaan dan kecerdasan yang optimal, serta skill yang dibutuhkan bagi diri sendiri dan masyarakat. Mutu dalam pendidikan adalah pendukung utama bagi pelaksanaan dan tercapainya output pembangunan masyarakat bangsa Indonesia yang bermartabat dan berkualitas.

Dalam penyelenggaraannya, mutu pendidikan bukan hanya diusahakan melalui transformasi wawasan pada ilmu pengetahan dan teknologi, namun peningkatan profesionalisme dan sistem manajemen tenaga pendidik dan kependidikan juga harus terus digencarkan untuk mencapai pendidikan yang bermutu tersebut. Lebih lanjut, mengembangkan SDM (Sumber Daya Manusia) juga dibutuhkan untuk meningkatkan kecakapan atau kemampuan siswa dalam menyelesaikan permasalahannya sendiri, serta mampu memilih dan mengambil keputusan demi tercapainya harapan dan cita-citanya. Dengan demikian, mutu pembelajaran tidak akan mencapai tujuan pendidikan apabila pendidikan tersebut tidak direncanakan dengan baik dan optimal. Kelemahan dalam segi perencanaan dan pelaksanaan inilah yang kemudian dapat menghambat tercapainya mutu belajar masing-masing siswa. Misalnya, perencanaa yang begitu baik dan matang, tidak diindahkan dengan kepatuhan terhadap peraturan tersebut. termasuk tidak adanya sanksi terhadap perilaku abai pada suatu peraturan. Tidak hanya di dalam pendidikan formal seperti sekolah formal, tetapi juga pendidikan non formal seperti di pesantren dan juga dalam keluarga. Faktanya, pendidikan di dalam keluarga yang diberikan oleh orangtua dapat membentuk karakter seseorang.

Pendidikan mampu membantu seseorang dalam mengaktualisasikan diri, selain itu, mampu mengoptimalkan akhlakul karimah, mengembangkan keterampilan serta pengetahuan baik di sekolah maupun di rumah. Sehingga, melalui pendidikan, seseorang dapat hidup bahagia dan bermanfaat dalam masyarakat luas. Dampak besar yang muncul akibat 
pendidikan tidak dapat disepelekan. Artinya, melalui pendidikan seseorang mampu bertransformasi menuju kehidupan yang lebih baik, yakni dari segi intelektual, moral, serta spriritual.

Pada ranah pendidikan, siswa dapat dikatakan unggul apabila dapat mematuhi aturan yang ada di sekolah serta dapat meningkatkan kedisiplinan. Siswa yang unggul tersebut juga tidak terlepas dari figur guru, dimana guru adalah salah satu faktor utama sebagai penentu keberhasilan dalam sebuah pendidikan. Figur guru berkaitan dengan bagaimana kinerja guru tersebut yang pada akhirnya dapat menentukan hasil dalam sebuah pendidikan. Kinerja guru merujuk pada beberapa hal. Menurut Ivancevich, rujukan kinerja guru meliputi: pertama, hasil yang merujuk kepada besaran output dalam suatu organisasi; kedua, efisisiensi yang merujuk kepada penggunaan sumber daya dalam organisasi; ketiga, kepuasan yang merujuk kepada keberhasilan organisasi untuk memenuhi kebutuhan anggotanya; dan yang keempat, adaptasi atau penyesuaian yang merujuk pada tanggapan organisasi terhadap adanya pergeseran sebagai suatu perubahan. Hal tersebut juga berlaku pada guru bimbingan dan konseling (BK), dimana pada dasarnya guru BK memfokuskan pada pemberian layanan untuk siswa (Direktorat Tenaga Kependidikan 2008). Meskipun demikian, kegiatan guru BK dinilai berbeda dengan guru mata pelajaran lainnya ataupun guru kelas.

Kegiatan yang dilakukan oleh guru BK diperuntukkan bagi para siswa-siswi, yakni kegiatan atau layanan bimbingan, yang disesuaikan dengan kebutuhan masing-masing individu. Layanan bimbingan adalah bentuk layanan atau kegiatan yang dilakukan oleh guru BK dalam penyusunan rencana pembimbingan, melakukan pembimbingan, dan melakukan perbaikan tindak lanjut bimbingan dengan memanfaatkan hasil evaluasi. Bimbingan yang diberikan oleh guru BK merupakan bagian dari layanan bagi siswa.

Berdasarkan SK Mendikbud No. 25/0/1995 mengenai layanan bagi siswa menyebutkan bahwa semua pelayanan dapat diberikan kepada para siswa secara individual ataupun klasikal atau kelompok. Guru BK dapat memberikan layanan kepada siswa dengan tujuan agar siswa mampu untuk hidup secara mandiri serta berkembang sesuai tahapan perkembangan secara optimal melalui berbagai jenis layanan dan kegiatan pendukung, sesuai dengan norma serta aturan yang berlaku (Arsini 2017). Guru adalah seorang pendidik yang profesional dengan berbagai macam tugas, dimana tugas utamanya adalah mendidik, memberikan pengajaran, bimbingan dan arahan, latihan, penilaian serta memberikan evaluasi terhadap pembelajaran yang dilakukan oleh siswa. lebih lanjut, guru BK atau konselor sekolah adalah guru dalam suatu sekolah yang mana mempunyai beban hak dan kewajiban, termasuk tugas, wewenang, serta tanggung jawab secara penuh dalam kegiatan pelayanan 
bimbingan dan konseling kepada siswa. Sama halnya dengan guru bidang studi lainnya, guru BK juga perlu untuk memperhatikan kinerjanya.

Kata kinerja berasal dari bahasa asing yaitu Bahasa Inggris, yakni 'performance', asal kata 'to perform', mempunyai arti 'menampilkan', 'melaksanakan'. Kata performance berkaitan dengan prestasi kerja, pelaksanaan kerja, pencapaian kerja, penampilan kerja atau unjuk kerja (Kamus Besar Bahasa Indonesia 2002). Selanjutnya, menurut Direktorat Tenaga Kependidikan, yang termaktub dalam "Penilaian Kinerja Guru" sebagai materi diklat, kinerja merupakan perwujudan dari perilaku seseorang atau organisasi yang berorientasi pada pencapaian prestasi (Direktorat Tenaga Kependidikan 2008).

Kinerja adalah tingkatan keberhasilan seorang atau sekelompok orang pada pelaksanaan tugas dan tanggung jawabnya, sehingga mampu untuk menggapai tujuan dan standar kerja yang telah ditentukan sebelumnya (Saondi dan Suherman 2010). Kinerja guru adalah suatu prestasi kerja atau hasil kerja (output) baik secara kualitas maupun kuantitas, dengan indikator tercapainya SDM (Sumber Daya Manusia) dalam melaksanakan tugasnya sesuai dengan hak, wewenang, dan tanggung jawabnya (Damin dan Suparno 2009; (Yamin dan Maisah 2010). Keberhasilan pelaksanaan tugas oleh guru dalam suatu pendidikan, dimaknai sebagai kinerja guru. Pelaksanaan tersebut berdasarkan standar kerja yang telah ditetapkan selama retang periode tertentu, dalam rangka mencapai tujuan pendidikan.

Kinerja guru sebagai seorang pendidik adalah respon yang tercermin dalam perilaku dalam memberikan hasil yang mengacu pada hal-hal tertentu yang dikerjakan saat menghadapi suatu tugas. Kinerja guru menyangkut segala kegiatan yang berdampak pada hasil atau tujuan dari kegiatan yang dilakukannya. Kinerja tersebut bertujuan secara khusus, sehingga mampu mentransfer perilaku tertentu kepada siswa. Sehingga dengan adanya kinerja guru atau pendidik yang baik dan professional sesuai dengan ranah dan tugastugasnya, maka akan menciptakan suasana belajar-mengajar dan semangat belajar siswa. Kinerja guru dapat diamati dan diukur menurut kualifikasi khusus yang dimiliki oleh masingmasing guru.

Konteks pada basis pendidikan lainnya menyebutkan bahwa, kinerja ini dipandang sebagai perluasan dari suatu tujuan perilaku. Sama halnya dengan tujuan pembelajaran dengan orientasi perubahan perilaku, pendidikan yang didasarkan pada kinerja guru seyogyanya tepat untuk diterapkan pada masing-masing bidang atau mata pelajaran. Perubahan perilaku digambarkan baik melalui penilaian dari hasil tes kinerja maupun pengamatan atau observasi terhadap suatu perilaku tertentu. 
Kinerja guru, khususnya guru BK merupakan respon perilaku yang dampaknya akan memberikan hasil sesuai dengan tujuannya terhadap siswa. Kinerja guru BK meliputi pemberian bimbingan dan pelayanan untuk membantu semua permasalahan serta membantu memaksimalkan perkembangan pribadi-sosial, belajar, dan karier siswa. Dengan demikian, kegiatan pelayanan tersebut akan menunjukkan hasil yang maksimal sesuai dengan kebutuhan siswa. Kinerja guru BK, diantaranya berupa layanan bimbingan konseling, yang juga berkaitan dengan kedisiplinan siswa.

Kedisiplinan siswa adalah gambaran dari kinerja guru BK di sekolah. Guru BK merupakan tenaga pendidik yang memegang tanggung jawab penuh terhadap kegiatan pelayanan bagi siswa, yakni kegiatan bimbingan dan konseling. Selain itu, guru BK seharusnya dapat pula memberi contoh yang baik bagi siswanya termasuk mengenai kedisiplinan. Kinerja guru BK yang mencerminkan pada sikap disiplin maka akan berdampak pada kedisiplinan siswa-siswi.

Kedisiplinan merupakan kepatuhan atau ketaatan terhadap suatu aturan tertentu yang dilaksanakan secara sadar serta tidak ada dorongan maupun paksaan dari pihak lain, sehingga tercipta keadaan yang tertib, teratur dan sebagaimana mestinya, sehingga tidak tercatat suatu pelanggaran baik secara langsung ataupun tidak langsung (Saondi dan Suherman 2010). Ketaatan dan kepatuhan tersebut muncul karena adanya kesadaran dalam diri seseorang atau sekelompok orang terhadap aturan-aturan yang telah ditetapkan sebelumnya. Disiplin adalah kecakapan seseorang dalam menggunakan waktu dalam melakukan hal-hal yang positif untuk mencetak suatu prestasi. Disiplin juga dapat berarti sebagai kemampuan dalam berperilaku sesuai aturan yang berlaku, sehingga mendatangkan kebermanfaatan untuk dirinya sendiri, orang lain, serta lingkungan. Namun faktanya, kedisiplinan merupakan hal yang paling sering dilanggar oleh sebagian atau bahkan banyak orang.

Pada dasarnya, masing-masing siswa mampu menerapkan kedisiplinan di sekolah. Tetapi, kedisiplinan yang ditujukkan oleh siswa juga harus diimbangi dengan kedisiplinan guru dalam mengajar. Bagaimana guru disiplin dalam berbagai hal, termasuk dalam pembelajaran. Misalnya, ketika seorang guru membuat peraturan tentang keterlambatan, terlambat 15 menit akan mendapat hukuman. Maka guru pun harus mematuhi peraturan tersebut. Apabila disiplin dapat dilakukan dengan kesadaran bersama maka akan memungkinkan terciptanya kelas yang kondusif serta lebih baik dalam proses penbelajaran. Maka dari itu, ketidakdisiplinan guru juga akan berpengaruh pada kedisiplinan siswa.

Berikut ini adalah beberapa contoh ketidakdisiplinan guru di sekolah, diantaranya adalah korupsi waktu, terlambat masuk kelas, sering izin, salah seragam, memainkan 
handphone, gadget atau media sosial saat jam pelajaran ataupun melakukan hal-hal lain di luar aktivitas pembelajaran. Dengan demikian, disiplin penting untuk diterapkan karena dapat mengakibatkan keberhasilan dalam sebuah proses pendidikan. Penerapan disiplin seyogyanya dilakukan oleh semua komponen yang terlibat dalam proses pendidikan, yaitu baik oleh para siswa, guru sebagai tenaga pendididik, maupun komunitas sekolah.

Temuan di lapangan menunjukkan bahwa tidak sedikit dari kedisiplinan siswa telah goyah, terutama kedisiplinan di sekolah. Hal tersebut terjadi karena banyak sebab, diantaranya adalah kurangnya teladan bagi para siswa yang seharusnya mampu diberikan oleh para pendidik dan tenaga kependidikan serta pemimpin sekolah atau kepala sekolah, serta inkonsistensi tata tertib sekolah yang seyogyanya ditaati. Inkonsistensi tata tertib dapat terjadi, karena rendahnya perhatian sekolah dalam penegakan aturan-aturan di lingkungan sekolah.

Maka dari itu, seharusnya pengelola sekolah mampu memprioritaskan konsistensi penegakan budaya disiplin di kalangan para siswa. Melalui konsistensi penegakan budaya disiplin, mampu mencetak perilaku dan prestasi siswa yang dapat dibanggakan. Sehingga, sejak awal seyogyanya guru mengenalkan lingkungan sekolah kepada para siswa, serta menunjukkan cara untuk menghargai dan menjunjung tinggi nilai-nilai kedisiplinan. Sekolah hendaknya mampu meyakinkan para siswa bahwa kedisiplinan tinggi yang diterapkan, mampu menghasilkan perilaku baik dan meraih prestasi yang gemilang. Sebaliknya, apabila kedisiplinan tiada, maka fungsi sekolah dapat dikatakan mandul, terlebih akan sangat sulit untuk mengeksplor potensi para siswa, bahkan banyak siswa yang dapat terlibat dalam suatu masalah tertentu. Penegakan kedisiplinan terhadap siswa serta konsistensi dalam pelaksanaannya, juga merupakan upaya guru untuk membantu siswa dalam menyesuaikan diri dengan peraturan-peraturan di sekolah yang harus dipatuhi.

Berkaitan dengan kedisiplinan, penyelenggaraan layanan bimbingan konseling yang diusahakan oleh guru BK, bertujuan agar individu mampu memecahkan permasalahan yang dihadapinya serta mampu menyesuaikan dirinya. Penyesuaian diri memiliki makna bahwa individu mampu menyesuaikan diri terhadap diri sendiri, lingkungan, dan termasuk menyesuaikan diri untuk berperilaku disiplin. Kedisiplinan siswa merupakan hasil penyesuaian dari sebuah proses interaksi yang dilakukan oleh para siswa dengan lingkungannya baik terhadap budaya, individu, ataupun hal-hal lainnya. Maka, sangat penting menciptakan lingkungan sekolah yang kondusif dengan penerapan disiplin, sehingga siswa memiliki sikap kedisiplinan. Islam juga menggarisbawahi bahwasanya menghargai waktu, 
yang merupakan cerminan untuk bersikap disiplin, adalah hal yang lebih utama, sebagaimana yang termaktub pada Surah Al-Ashr, Allah SWT. berfirman;

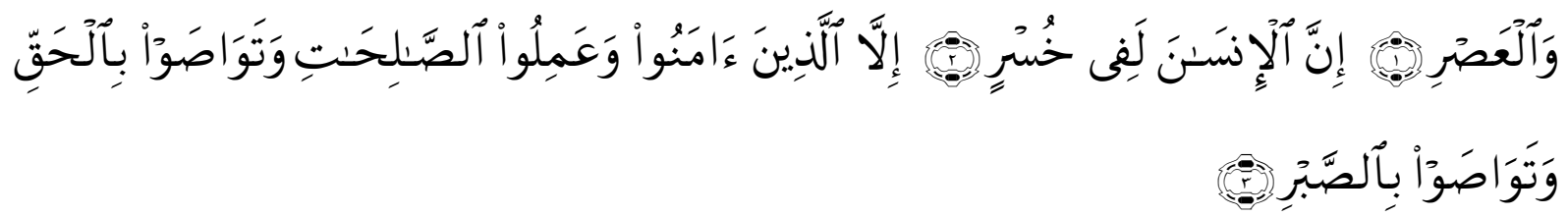

Artinya; "Demi masa. Sesuangguhnya manusia benar-benar dalam kerugian. Kecuali bagi orang-orang yang beriman \& mengerjakan amal shaleh dan menasehati agar supaya menaati kebeneran dan saling menasehati supaya menetapi kesabaran”.

Disiplin yang dilakukan oleh diri sendiri dilakukan karena adanya kesadaran bahwa prestasi diri tidak dapat dicapai tanpa kerja keras dan perilaku yang baik. Prestasi dapat diraih tidak hanya bermodalkan kecerdasan, namun juga diperoleh melalui kedisiplinan yang tinggi dalam proses belajar dan melakukan sesuatu yang baik pula sesuai dengan tugas dan kewajibannya sebagai siswa di sekolah.

Fenomena yang terjadi di SMK Al-Huda Sumbernangka Larangan Pamekasan, berdasarkan hasil wawancara peneliti terhadap siswa diperoleh informasi bahwa 1) siswa sering menyepelekan Guru BK, 2) Siswa acuh tak acuh terhadap tata tertib sekolah, 3) Siswa sering terlambat. Ketiga hal tersebut merupakan bagian dari kedisiplinan yang harus ditaati oleh semua siswa.

Menurut guru Mata Pelajaran Bahasa Indonesia di SMK Al-Huda, yaitu Ibu Hasna, proses pembelajaran masih minim akan sarana dan prasarana, dalam hal ini kurangnya ruang khusus guru BK, sebagai ruangan yang idealnya digunakan dalam proses memberikan layanan bimbingan konseling. Minimnya sarana \& prasarana kegiatan bimbingan konseling ini berimplikasi pasa kedisiplinan siswa. Kedisiplinan terbentuk melalui suatu proses yang menunjukkan serangkaian sikap seperti nilai-nilai ketaatan atau kepatuhan dan keteraturan atau ketertiban. Oleh karena itu, kedisiplinan di SMK Al-Huda Sumbernangka Larangan Pamekasan harus benar-benar ditegakkan karena kedisiplinan harus dimiliki oleh siswa sejak dini agar dapat mengembangkan kecerdasan, kepribadian, akhlak serta kecakapan tertentu yang diperlukan bagi dirinya.

Berdasarkan latar belakang di atas, gambaran kedisiplinan siswa di SMK Al-Huda ditunjukkan dengan perilaku-perilaku ketidakdisiplinan siswa. Hal tersebut berkaitan dengan kinerja guru BK. Dengan demikian, penting untuk dilakukan penelitian tentang "Pengaruh Kinerja Guru BK Terhadap Kedisiplinan Siswa di SMK Al-Huda Sumbernangka Larangan Pamekasan”. 


\section{METODE}

Penelitian ini menggunakan pendekatan kuantitatif. Peneliti menggunakan analisis data statistik untuk menganalisis temuan penelitian, dimana analisis tersebut menekankan pada data data numerical (angka). Sedangkan sifatnya yaitu menggunakan sifat korelasi, yaitu dengan mencari suatu hubungan antar variabel, serta melihat bagaimana pengaruhnya. Penelitian ini terdiri atas variabel X dan Y. Variabel X (independent variable) adalah 'kinerja guru' dan variabel Y (dependent variable) adalah 'kedisiplinan siswa'. Penelitian ini dilakukan di SMK Al-Huda Sumbernangka Larangan Pamekasan. Teknik purposive sampling digunakan untuk menentukan subyek penelitian. Subyek penelitian sebanyak 64 siswa.

Penelitian ini menggunakan berbagai sumber data, yakni primer dan sekunder. Sumber data primer adalah sumber data yang secara langsung memberikan data-data tertentu kepada peneliti. Data primer dalam penelitian ini adalah kuesioner atau angket. Sedangkan sumber data sekunder merupakan sumber data dimana data diberikan secara tidak langsung kepada peneliti, misalnya dokumen, absensi siswa dan semua yang berbetuk dokumen data sesuai dengan kebutuhan penelitian.

Teknik pengumpulan data melalui kuesioner atau angket, pengamatan atau observasi, dan dokumentasi. Dengan beberapa teknik ini dapat memungkinkan peneliti mendapatkan validitas data sesuai dengan tujuan penelitian. Selanjutnya, peneliti melakukan analisis data, yaitu setelah fakta informasi yang diperoleh dari tahap pengumpulan data, data yang dihimpun dalam catatan yang berupa data kuesioner atau angket dianalisis menggunakan bantuan SPSS, serta analisis terhadap hasil observasi dan dokumentasi yang dianalisis secara mendalam.

Penelitian ini menggunakan teknik analisis data berupa analisis korelasi, Product Moment serta selanjutnya digunakan analisis regresi linier sederhana. Analisis korelasi digunakan untuk mengetahui hubungan antar variabel, yaitu untuk mengetahui hubungan antara kinerja guru BK dengan kedisiplinan siswa. Sementara penggunaan analisis regresi bertujuan untuk melihat pengaruh kinerja guru BK terhadap kedisiplinan siswa, sehingga melalui penelitian ini dapat diketahui prosentase kontribusi kinerja guru bimbingan terhadap konseling terhadap kedisiplinan siswa.

\section{HASIL}

Kinerja guru BK merupakan respon perilaku yang dampaknya memberikan hasil sesuai dengan tujuannya terhadap siswa yaitu memberikan bimbingan dan pelayanan, membantu semua permasalahan, menstimulasi bidang pribadi-sosial, belajar dan karier para 
siswa. Oleh karena itu, sebagai guru BK harus betul-betul maksimal dalam memberikan pelayanan terhadap siswa, agar siswa mempunyai karakter dan kedisiplinan yang baik di sekolah.

Tujuan penelitian ini adalah untuk mengetahui hungungan antara kinerja guru bimbingan dengan konseling terhadap kedisiplinan siswa, serta pengaruh kinerja guru BK terhadap kedisiplinan siswa di SMK Al-Huda Sumbernangka Larangan Pamekasan. Penelitian yang dilakukan di SMK Al-Huda Sumbernangka Larangan Pamekasan ini, menunjukkan bahwa pertama, terdapat hubungan yang positif dan signifikan antara kinerja guru BK dengan kedisiplinan siswa. Hal tersebut ditunjukkan melalui nilai koefisien korelasi sebesar 0,556, dimana $r_{\text {hit }}$ lebih besar daripada $r_{\text {tabel }}\left(r_{\text {hit }}>r_{\text {tabel }}, 0,556>0,2461\right)$.

Pengelompokan koefisien korelasi (keeratan hubungan) antar variabel dapat ditunjukkan sebagai berikut (Sujarweni 2014), nilai koefisien korelasi sebesar:

1. 0,00 - 0,20 yang mempunyai arti 'hubungan sangat lemah';

2. 0,21 - 0,40 yang mempunyai arti 'hubungan lemah';

3. 0,41 - 0,70 yang mempunyai arti 'hubungan kuat';

4. 0,71 - 0,90 yang mempunyai arti 'hubungan sangat kuat';

5. 0,91 - 0,99 yang mempunyai arti 'hubungan kuat sekali';

6. 1,00 yang mempunyai arti 'hubungan sempurna'.

Hasil penelitian ini menunjukkan bahwa nilai koefisien korelasi $\left(\mathrm{r}_{\mathrm{hit}}\right)$ sebesar 0,556, yang memiliki makna bahwa terdapat hubungan yang kuat antara kinerja guru BK dengan kedisiplinan siswa di SMK Al-Huda Sumbernangka Larangan Pamekasan.

Kedua, berdasarkan hasil penelitian yaitu hubungan kuat yang positif, berarti bahwa semakin tinggi kinerja guru BK, maka akan semakin tinggi pula tingkat kedisiplinan siswa. Semakin rendah kinerja guru BK, maka akan semakin rendah pula tingkat kedisiplinan siswa. Maka dari itu, tingkat kinerja guru bimbingan konseling, dapat menentukan tingkat kedisiplinan siswa.

Ketiga, kinerja guru BK memiliki pengaruh terhadap kadar kedisiplinan siswa. Hasil penelitian ini membuktikan jika kinerja guru BK mampu memberikan sumbangan efektif atau berkontribusi sebesar 31\% terhadap kedisiplinan siswa, sedangkan 69\% sisanya dipengaruhi oleh faktor lain sebagai variabel yang tidak dilibatkan dalam penelitian ini. 


\section{PEMBAHASAN}

Kedisiplinan siswa adalah kondisi tertib serta teratur yang dilakukan oleh para siswa di sekolah yang ditunjukkan dengan perilaku dengan tanpa melakukan pelanggaranpelanggaran tertentu yang dapat merugikan diri sendiri maupun pihak sekolah secara keseluruhan, baik berdampak secara langsung maupun tidak langsung (Huda 2010). Disiplin merupakan organizational frame yang memungkinkan seseorang untuk mengerjakan suatu hal tertentu (Daradjat 2011).

Disiplin memiliki beberapa indikator, pertama, memiliki sikap mental (mental attitude) dalam menaati peraturan (tata tertib) sebagai hasil ataupun pengembangan diri dari latihan, sehingga mampu mengendalikan watak dan pikiran. Kedua, memiliki pemahaman yang baik tentang sistem peraturan perilaku, norma kriteria dan standar peraturan sehingga menimbulkan kesadaran yang mendalam terhadap suatu aturan. Ketiga, memiliki sikap atau perilaku yang menunjukkan kesungguhan untuk mentaati segara peraturan atau tata tertib yang berlaku (Purwanto 2009). Siswa yang memiliki perilaku disiplin, tercermin dalam beberapa indikator tersebut.

Disiplin perlu ditegakkan, karena disiplin memiliki berbagai manfaat. Manfaat disiplin, diantaranya pertama, memberikan rasa aman dan memberikan rambu-rambu terhadap apa yang dapat diperbuat dan yang tidak dapat diperbuat. Kedua, disiplin memungkinkan seseorang untuk hidup sesuai standar yang disepakati oleh lingkungan sosial. Ketiga, memungkinkan seseorang belajar untuk bersikap sesuai aturan, yang merupakan bagian dari penyesuaian diri terhadap lingkungan sekitar. Keempat, disiplin yang dilakukan, memiliki fungsi sebagai motivasi bagi ego yang mampu mendorong seseorang untuk mencapai hal-hal apa yang diharapkannya (Ismaya 2015). Disiplin memiliki banyak manfaat, sehingga disayangkan untuk mengabaikan kedisiplinan. Maka dari itu, penegakan disiplin serta konsistensi untuk berperilaku disiplin sangat penting untuk dilakukan.

Dengan demikian, para guru dan juga guru BK hendaknya mampu mempersiapkan diri dan siswa dalam hal kedisiplinan. Kedisiplinan berkaitan dengan kinerja guru BK. Kinerja dapat dimaknai sebagai pencapaian dari hasil usaha seseorang disertai dengan adanya kemauan yang direfleksikan dalam suatu perbuatan tertentu (Wahyudi 2012). Kinerja merupakan tingkat keberhasilan individu atau kelompok dalam pelaksanaan tugas dan tanggung jawabnya. Kinerja adalah dampak kemampuan dalam mencapai tujuan dan standar yang sebelumnya telah ditentukan (Saondi dan Suherman 2010).

Kinerja guru merupakan kualitas maupun kuantitas dari hasil kerja seorang guru. Hasil kerja tersebut dicapai oleh guru dalam menuntaskan tugasnya berdasarkan wewenang 
dan tanggung jawabnya (Damin dan Suparno 2009; Yamin dan Maisah 2010; Wahyudi 2012). Kinerja guru merujuk pada kualitas dan kuantitas hasil dalam meraih prestasi yang dilakukan oleh guru, yang telah dicapai dalam melaksanakan tugas-tugas sesuai tanggung jawabnya, berdasarkan kecakapan, pengalaman, serta dedikasinya.

Kinerja guru dapat ditinjau melalui beberapa indikator, yaitu kemampuan dalam membuat perencanaan sebagai persiapan pembelajaran; penguasaan materi dalam proses pembelajaran yang akan disampaikan pada siswa; penguasaan metode pembelajaran, strategi pembelajaran; pemberian tugas; kemampuan mengelola kelas; serta kemampuan dalam melakukan penilaian dan evaluasi. Adapun faktor-faktor yang dapat mempengaruhi kinerja guru meliputi kerpribadian dan dedikasi; kemampuan memberikan pengajaran; kemampuan dalam mengembangkan profesi; komunikasi; kemampuan bersosialisasi dengan masyarakat sekitar; kedisiplinan; kesejahteraan; serta iklim kerja (Saondi dan Suherman 2010). Dengan adanya kinerja guru, khususnya guru BK sebagai pendidik yang baik dan professional sesuai dengan ranah dan tugas-tugasnya maka akan menciptakan suasana belajar-mengajar yang kondusif, memunculkan semangat belajar siswa yang maksimal, serta mampu membentuk perilaku disiplin siswa.

Beberapa penelitian yang telah dilakukan, membuktikan bahwa kinerja guru mempengaruhi kedisiplinan siswa. Penelitian yang dilakukan di Kota Malang, tentang kinerja guru SMKN berpengaruh terhadap kedisiplinan siswa (Afrilia 2014). Penelitian yang dilakukan di SMK Muhammadiyah 1 Seputih Banyak Lampung Tengah, menyebutkan bahwa kinerja guru berpengaruh terhadap disiplin belajar siswa (Purniawati 2018). Selanjutnya, kinerja guru BK, dalam hal ini layanan bimbingan konseling yang diberikan oleh guru BK sebagai konselor sekolah mampu memberikan kontribusi terhadap kedisiplinan siswa. Hal tersebut dibuktikan dalam penelitian mengenai pengaruh layanan bimbingan konseling di MTs. N Penago II Seluma terhadap kedisiplinan siswa, menunjukkan bahwa layanan bimbingan konseling berpengaruh terhadap kedisiplinan siswa. Layanan bimbingan konseling yang diberikan terhadap siswa tersebut meliputi layanan orientasi, layanan informasi, layanan konseling individu, serta layanan konsultasi (Sugiarti 2017). Penelitian terdahulu menunjukkan bahwa kinerja guru BK berpengaruh terhadap kedisiplinan para siswa.

Penelitian ini bertujuan untuk mengetahui apakah terdapat pengaruh kinerja guru BK terhadap kedisiplinan siswa SMK Al-Huda Sumbernangka Larangan Pamekasan. Hasil penelitian menujukkan bahwa terdapat pengaruh kinerja guru BK terhadap kedisiplinan siswa di SMK Al-Huda Sumbernangka Larangan Pamekasan. Kinerja guru BK merupakan salah 
satu faktor yang mempengaruhi kedisiplinan siswa, dengan kontribusi sebanyak $31 \%$ sedangkan sisanya yakni $69 \%$ dipengaruhi oleh faktor lainnya.

Secara umum, tugas dan kewajiban guru dalam Undang-undang No. 14 tahun 2005 pasal 20 yaitu pertama, merencanakan pembelajaran, melaksanakan pembelajaran yang bermutu, serta memberikan penilaian \& evaluasi hasil pembelajaran. Kedua, meningkatkan serta mengembangkan kualifikasi akademik dan kompetensi secara berkelanjutan sesuai dengan iptek dan kesenian. Ketiga, bersikap objektif serta non-diskriminatif terhadap siswa dari berbagai latar belakang, baik jenis kelamin, suku, agama, ras, golongan, latar belakang keluarga, ataupun status sosial ekonomi (Masnun 2014). Tugas dan kewajiban tersebut juga berlaku bagi guru BK, misalnya pelayanan bimbingan konseling yang dilakukan oleh guru BK, meskipun pada dasarnya terdapat sedikit perbedaan.

Diketahui bahwa dalam penelitian ini membuktikan jika semakin tinggi kinerja guru BK, maka akan semakin tinggi juga tingkat kedisiplinan siswa. Sebaliknya, jika semakin rendah kinerja guru BK, maka akan semakin rendah juga tingkat kedisiplinan siswa. Maka dari itu, penting bagi para guru, khususnya guru BK untuk meningkatkan kinerja, salah satunya dengan pemberian bantuan kepada siswa melalui layanan bimbingan konseling yang profesional sesuai kebutuhan masing-masing siswa. Selanjutnya, melalui penelitian ini, diharapkan mampu memberikan wawasan sebagai tambahan referensi mengenai bimbingan konseling, khususnya yang berkaitan dengan kinerja guru BK dan kedisiplinan siswa. Kedisiplinan siswa dipengaruhi oleh beberapa hal, termasuk kinerja guru BK yang berkontribusi terhadap kedisiplinan siswa. Maka dari itu penting dilakukan penelitian lebih lanjut yang berkaitan dengan bimbingan konseling, terutama sebagai usaha penerapan kedisiplinan yang konsisten yang selanjutnya berdampak pada optimalisasi potensi siswa dalam rangka mencetak generasi unggul.

\section{SIMPULAN}

Berdasarkan fokus penelitian, hasil penelitian menyimpulkan:

1. Terdapat hubungan yang positif dan signifikan antara kinerja guru BK dengan kedisiplinan siswa, dengan nilai koefisien korelasi sebesar $0,556\left(r_{\text {hit }}>r_{\text {tabel }} ; 0,556>\right.$ 0,2461). Nilai koefisien tersebut berada pada rentang hubungan yang kuat antar variabel kinerja guru BK \& kedisiplinan siswa tersebut.

2. Hasil tersebut menunjukkan jika semakin tinggi kinerja guru BK, maka akan semakin tinggi juga tingkat kedisiplinan siswa. Serta, semakin rendah kinerja guru BK, maka akan semakin rendah juga tingkat kedisiplinan siswa; 
3. Kinerja guru BK berpengaruh signifikan terhadap kedisiplinan siswa. Kinerja guru BK berpengaruh terhadap kedisiplinan siswa dengan kontribusi sebanyak 31\%, sedangkan $69 \%$ lainnya dipengaruhi oleh faltor lainnya sebagai variabel lain yang tidak dilibatkan pada penelitian ini.

\section{DAFTAR RUJUKAN}

Afrilia, Vinda. 2014. "Pengaruh Kinerja Guru Terhadap Kedisiplinan Peserta Didik." Manajemen Pendidikan 24 (4): 10.

Arsini, Yenti. 2017. "Konsep Dasar Pelaksanaan Bimbingan Konseling." Jurnal Raudhah 5 (1). https://doi.org/10.30829/raudhah.v5i1.137.

Barnawi, dan Mohamad Arifin. 2012. Kinerja Guru Profesional. Yogyskarta: Ar-Ruzz Media.

Damin, Sudarwan, dan Suparno. 2009. Manajemen dan Kepemimpinan Transformasional Kekepalasekolahan: Visi dan Strategi Sukses Era Teknologi, Situasi Krisis dan Internasional Pendidikan. Jakarta: Rineka Cipta.

Daradjat, Zakiah. 2011. Metodik Khusus Pengajaran Agama Islam. Jakarta: Bumi Aksara.

Daryanto, dan Mohammad Farid. 2015. Bimbingan Konseling Panduan Guru BK dan Guru Umum. Yogyakarta: Gava Media.

Direktorat Tenaga Kependidikan. 2008. Penilaian Kinerja Guru. Jakarta: Direktorat Tenaga Kependidikan, Dirjen PMPTK, Depdiknas.

Hartinah, Sitti. 2010. Konsep Dasar Bimbingan Kelompok. Bandung: PT Refika Aditama.

Huda, M. 2010. Kajian Filosofis Otonomi Daerah Bidang Kajian Pendidikan. Malang: UM Fakultas Ilmu Pendidikan.

Ismaya, Bambang. 2015. Bimbingan dan Konseling. Jakarta: Rineka Cipta.

Kamus Besar Bahasa Indonesia. 2002. Ketiga. Jakarta: Balai Pustaka.

Masnun, Moh. 2014. "Strategi Peningkatan Kinerja Guru." Al Ibtida: Jurnal Pendidikan Guru MI 1 (2). https://doi.org/10.24235/al.ibtida.snj.v1i2.351.

Musfah, Jejen. 2015. Manajemen Pendidkan Teori Kebijakan dan Praktik. Jakarta: Prenadamedia Group.

Nurihsan, Achmad Juntika. 2010. Manajemen Pendidkan Teori Kebijakan dan Praktik. Bandung: PT Refika Aditama.

Priatna, Nanang, dan Tito Sukamto. 2013. Pengembangan Profesi Guru. Bandung: PT Remaja Rosdakarya.

Purniawati, Ria. 2018. "Pengaruh Kinerja Guru Terhadap Disiplin Belajar Siswa SMK Muhammadiyah 1 Seputih Banyak Lampung Tengah.” Skripsi, Lampung: IAIN Metro.

https://repository.metrouniv.ac.id/id/eprint/2696/1/RIA\%20PURNIAWATI.pdf.

Purwanto, M. Ngalim. 2009. Prinsip-Prinsip dan Teknik Evaluasi Pengajaran. Jakarta: Remaja Rosdakarya.

Saondi, Ondi, dan Aris Suherman. 2010. Etika Profesi Keguruan. Bandung: Refika Aditama. Subini, Nini. 2012. Awas Jangan Jadi Guru Karbitan. Jakarta: PT Buku Kita.

Sugiarti. 2017. "Layanan Bimbingan Konseling Pada Kedisiplinan Siswa Di Madrasah Tsanawiyah Negeri Penago II Seluma." IAIN Bengkulu. http://repository.iainbengkulu.ac.id/3128/1/SKRIPSI\%20SUGIARTI\%20CD.pdf.

Sugiyono. 2012. Metode Penelitian Bisnis. Bandung: Alfabeta.

Sujarweni, V. Wiratna. 2014. SPSS untuk Penelitian. Yogyakarta: Pustaka Baru Press.

Susanto. 2010. Pemikiran Pendidikan Islam. Jakarta: Amzah. 
Wahyudi, Imam. 2012. Mengejar Profesionalisme Guru. Jakarta: Prestasi Pustaka.

Yamin, Martinis, dan Maisah. 2010. Standarisasi Kinerja Guru. Jakarta: GP Press Group. 